\section{Regards sur l'économie allemande}

Bulletin économique du CIRAC

$95 \mid 2010$

Varia

\title{
Loi fondamentale
}

ROBERTSON- von TROTHA Caroline Y. (ed), 60 Jahre Grundgesetz. Interdisziplinäre Perspektiven

\section{(2) OpenEdition}

\section{Journals}

Édition électronique

URL : http://journals.openedition.org/rea/4064

DOI : $10.4000 /$ rea.4064

ISBN : 978-2-8218-0886-7

ISSN : 1965-0787

Éditeur

CIRAC

Édition imprimée

Date de publication : 1 mars 2010

ISSN : 1156-8992

Référence électronique

«Loi fondamentale », Regards sur l'économie allemande [En ligne], 95 | mars 2010, mis en ligne le 08 mars 2010, consulté le 22 septembre 2020. URL : http://journals.openedition.org/rea/4064; DOI : https://doi.org/10.4000/rea.4064

Ce document a été généré automatiquement le 22 septembre 2020

(C) CIRAC 


\section{Loi fondamentale}

ROBERTSON- von TROTHA Caroline Y. (ed), 60 Jahre Grundgesetz. Interdisziplinäre Perspektiven

\section{RÉFÉRENCE}

ROBERTSON- von TROTHA Caroline Y. (ed), 60 Jahre Grundgesetz. Interdisziplinäre Perspektiven, Coll. Kulturwissenschaft interdisziplinär, Nomos, Baden-Baden, 2009, 296 p.

Pour le $60^{\mathrm{e}}$ anniversaire de la République fédérale, établie sur la Loi fondamentale entrée en vigueur le 23 mai 1949, voici un vaste panorama d'approches interdisciplinaires de la réalité vivante de cette Constitution. Le présent ouvrage rassemble les diverses contributions présentées sur ce sujet au cours du semestre d'hiver 2008/09 au Colloquium Fundamentale, série de conférences du Zentrum für Angewandte Kulturwissenschaft (ZAK) et du Sudium generale de l'Université technique de Karlsruhe. Comme il se doit, ces actes s'ouvrent sur celle de Hans-Jürgen Papier, président du Tribunal constitutionnel fédéral, et qui s'intitule : « La Constitution et son évolution ». On y lira également avec profit cette de Wolfgang Schäuble, ministre fédéral de l'Intérieur au moment du Colloquium, et consacrée au délicat équilibre entre l'exigence de ses principes et la réalité. (ib) 